\title{
EXPLORING SPEAKING STRATEGIES EMPLOYED BY INDONESIAN EFL TERTIARY STUDENTS
}

\section{Wawa Puja Prabawa*)}

Surel:wawapuja@gmail.com

\begin{abstract}
This study is a descriptive research since its purpose is to describe the Indonesian EFL tertiary students' learning strategies in learning speaking English. The result of the study revealed that some speaking strategies are employed in terms of speaking English and improve speaking ability, namely cognitive, metacognitive and compensation strategy. In the type of speaking strategy that mostly employed by the students in terms of speaking English is compensation strategy, while cognitive strategy was indicated as the mostly speaking strategies employed by the Indonesian EFL tertiary students in improving their speaking ability.
\end{abstract}

Keywords: Speaking, Strategy, Speaking Strategy, Tertiary Students

\section{INTRODUCTION}

People usually learn English because for some reasons, in some Language means something ways, they want to be able to spoken. People usually speak or communicate in English (Edge, share their opinion with one another 1993, p. 17). Furthermore, he points out that people are motivated to learn English as the language of International language (p. 18.). In Indonesia, English becomes one of the important subjects to be mastered by students at school, start from by using it. By mastering speaking, they can carry out conversation with others, give ideas and change the information with interlocutors (Fajariyah, 2009, 14). It means that speaking has a role in the language skill.

kindergarten up to university students.

*) Wawa Puja Prabawa, Dosen STKIP Pasundan Cimahi 
Among the four language skills, learners consider speaking as the most difficult one since it needs great courage as well as preparation to produce the language. Their personalities play a large role in determining how quickly and how correctly they will accomplish this skill. Those who are risk-takers unafraid of making mistakes will generally be more talkative, but they do not realize with the errors they make. Meanwhile, the conservative, shy students may take a long time to speak confidently, but when they do, they will make fewer errors and be proud of their English ability. Learners will think about which one is better, to talk much with many errors or to think more with better result. It can be answered when the aims of speaking is clearly stated, that is to build meaningful communication. In this case, to encourage learners to talk as much as possible to convey the messages of communication is more important rather than to let them think about grammar rules they use (Malihah, 2010, p. 86).

It is a common thing facing difficulties in learning speaking
English. The most important thing is how the students deal with such problem. Cohen (1998, p. 66) in Rahmadani, Amri and Adnan (2014, p. 413) states that language learning will be easier if the students become more aware of possible strategies that can be selected during learning and using language. He also believes that the students' language skill can be improved by themselves when they become more aware of what helps them to learn the language they are studying most efficiently.

Every students has their own learning strategies in studying English. It can be seen from the successful students rather than method or techniques of teaching. After observing and teaching some students in one of Schools of Higher Education in Cimahi majoring in English Education Study Program, some of them have low participation in speaking activity in the classroom. On one hand, the students' less participation in the classroom caused the students' low achievement in speaking. On the other hand, some of the students were active in speaking activity in the classroom. They also have good achievement in speaking. 
Some experts have been tried to define learning strategies. Wahyuni (2013, p. 4) provides some definitions from them that there is no consensus about the definition of learning strategies. Researchers (for example Brown, 2000; Cohen, 1990; Green and Oxford, 1995; Griffiths, 2008; O’Malley and Chamot, 1990; Oxford, 1990; Rubin, 1975; Stern, 1992; Wenden and Rubin, 1987) define language learning strategies in slightly different ways, causing a debate about whether they are physical or mental, conscious or subconscious, and problem-or goaltriggered.

O'Malley (1985, p.23) provides broad definition of language learning strategies as "any set of operations or steps used by a learner that will facilitate the acquisition, storage, retrieval or use of information." Griffiths (2008) defines learning strategies as "activities consciously chosen by learners for the purpose of regulating their own language learning (p.87)." Besides, Nunan (1999, p. 171) defines "learning strategies are the mental and communicative procedures learners use in order to learn and use language."

In addition, Wahyuni (2013) reported that the correlation between overall speaking strategy use and speaking proficiency is not significant, though positive. However, the effect of gender on strategy preference is found significant on affective strategies. Whereas, Moriam (2005) who investigated Japanese and Bangladeshi university students, found that Bangladeshi employ cognitive and interpersonal strategies more than Japanese, and that gender difference of both groups provides insignificant effect of the use of speaking strategies, except that cognitive strategies used by Japanese females are found to be higher than those by the male.

Meanwhile, Larenas (2011), investigated speaking strategies used by eight and twelfth graders, found that $8^{\text {th }}$ graders claim to have broader knowledge of speaking strategies than $12^{\text {th }}$ year secondary students, and the knowledge of speaking strategies of elementary and secondary school students does not 
vary depending on the type of school: public, semi-public and/or private.

Based on the explanation above, the present study was conducted in order to see kinds of learning strategies used by the students of English Education Study Program in one of School of Higher Education in Cimahi. This study analyzed the learning strategies used by the students in learning speaking English.

Table 1. Language Learning Strategies for Speaking Classified by Oxford (1990)

\section{Groups of Types of Learning Learning Strategies for Speaking Strategies Strategies}

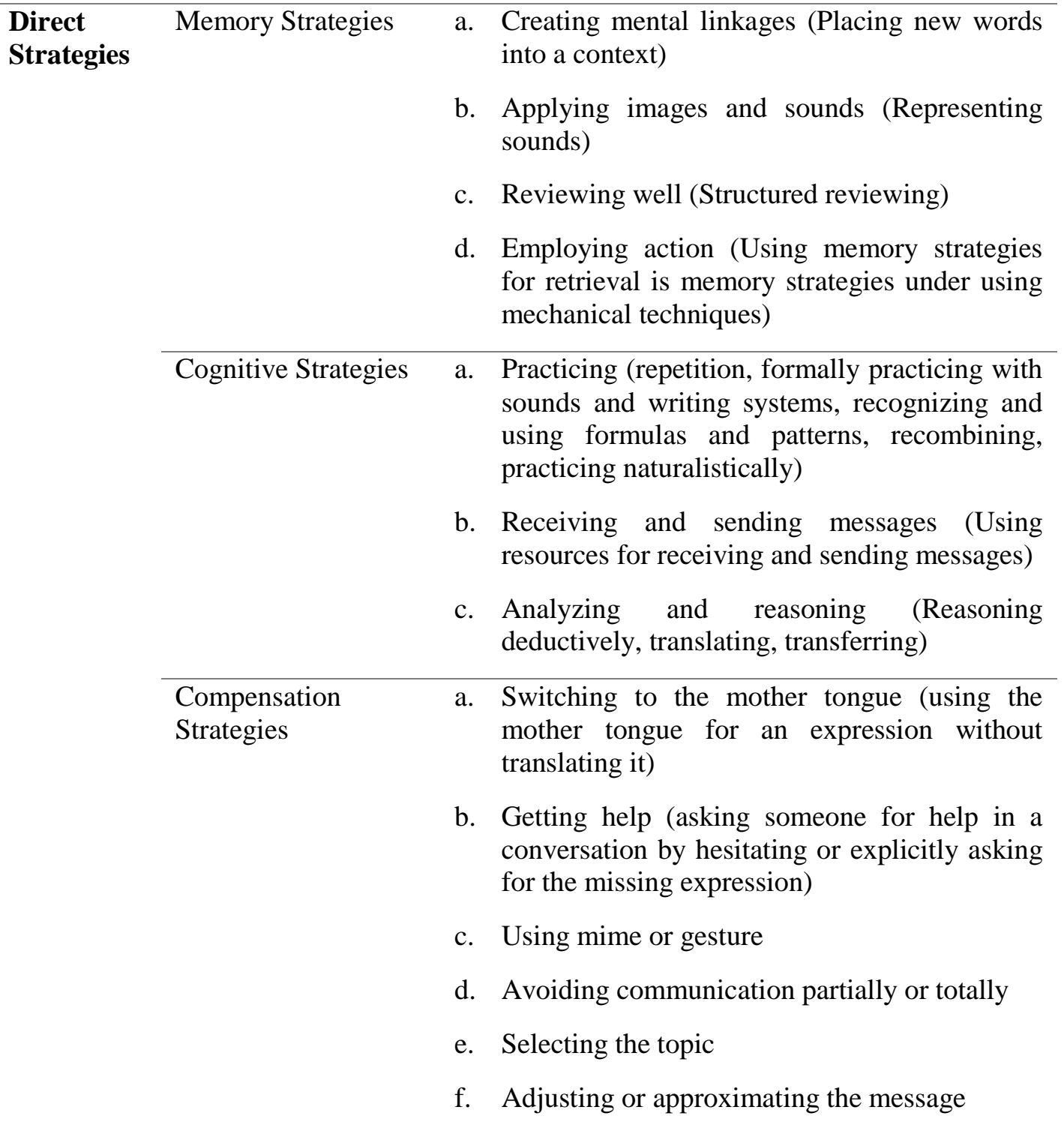




\section{g. Coining words}

h. Using a circumlocution or synonym

$\begin{array}{ll}\text { Indirect } & \text { Metacognitive } \\ \text { Strategies } & \text { Strategies }\end{array}$

a. Centering the learning (overviewing and linking already known material, attention involves directed attention and selected attention, delaying speech production to focus listening)

b. Arranging and planning the learning (Finding out about language learning, Organizing, Setting goals and objectives, Identifying the purpose of a language task, Planning for a language task, Seeking practice opportunity)

c. Evaluating the learning (self-monitoring, selfevaluating)

\begin{tabular}{ll}
\hline Affective Strategies & a. Lowering your anxiety \\
& b. Encouraging yourself \\
& c. Taking your emotional temperature \\
& d. Rewarding oneself for good performance \\
e. Using deep breathing or positive self-talk & a. Asking questions to get verification \\
\hline Social Strategies & b. Asking for clarification \\
c. Asking for help in doing a language task \\
d. Cooperating with others, talking with a native- \\
e. Empaking conversation partner \\
and social norms
\end{tabular}

These strategies can be specified as follows: 1) Memory strategies for remembering and retrieving new information. 2) Cognitive strategies for understanding and producing the language. 3) Compensation strategies for using the language despite lack of knowledge. 4) Metacognitive strategies for coordinating the learning process. 5) Affective strategies for regulating emotions. 6) Social strategies for learning with others (Oxford, 1990, p. 14-15).

\section{METHODOLOGY}


This study was a descriptive research since its purpose was to describe the Indonesian EFL tertiary students' learning strategies in learning speaking English.

The data, strategy that has the highest score, was indicated as a strategy mostly employed by the students. Then, the results were analyzed by using simple scaling percentage to see the strategy which was mostly used by all the students. The percentage formula is as follow:

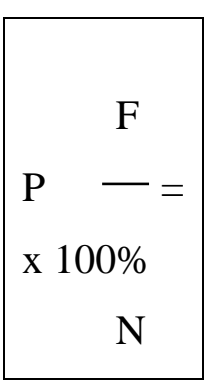

Where:

$\mathrm{P}$ : Percentage

$\mathrm{F}$ : Frequency of answer

$\mathrm{N}$ : Total respondents

After classifying, the data was interpreted to get general conclusion. The strategy that has the highest score was indicated as a strategy mostly used by the students.

Table 2. Average Percentage of Speaking Strategies Used by Indonesian Tertiary Students

\begin{tabular}{llcc}
\hline \multicolumn{2}{c}{ Types of Strategies } & Frequency & Percentage \\
\hline $\begin{array}{l}\text { In terms of } \\
\text { Speaking English }\end{array}$ & $\begin{array}{l}\text { Compensation } \\
\text { Strategy }\end{array}$ & 14 & $93.33 \%$ \\
\cline { 2 - 4 } & $\begin{array}{l}\text { Metacognitive } \\
\text { Strategy }\end{array}$ & 1 & $6.67 \%$ \\
\hline $\begin{array}{l}\text { Improving } \\
\text { Speaking Ability }\end{array}$ & $\begin{array}{l}\text { Cognitive } \\
\text { Strategy }\end{array}$ & 13 & $86.67 \%$ \\
\hline & $\begin{array}{l}\text { Metacognitive } \\
\text { Strategy }\end{array}$ & 2 & $13.33 \%$ \\
\hline
\end{tabular}

\section{In terms of Speaking English}

From the table 2 above, it is shown that in terms of speaking English, there were two strategies used by the students: compensation and metacognitive strategy. 10 students used circumlocution and synonym, 3 students used gesture, 
and 1 student used switching to mother tongue as their compensation strategy. Meanwhile, 1 student used metacognitive strategy by applying

\section{Diagram 1. Speaking Strategies Mostly Employed by Indonesian Tertiary} Students

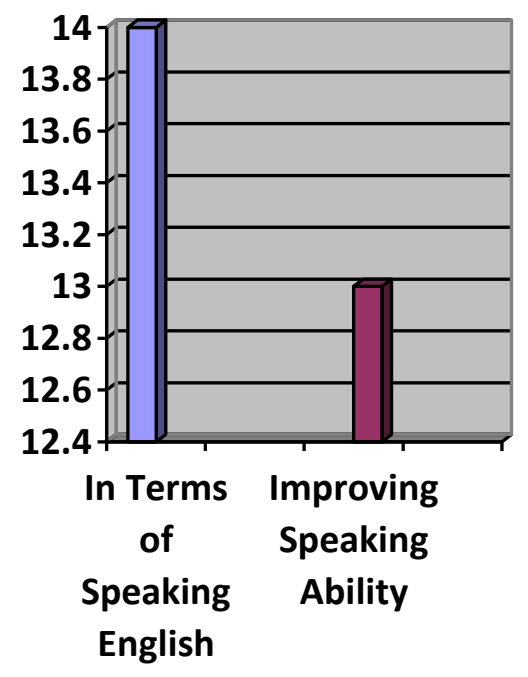

evaluating and learning, making correction of himself when he makes an error.
From the diagram 1 above, there were 14 students or about $93.33 \%$ used compensation strategy as their speaking strategy when they speak English. They mostly used synonym to explain the word in English. Al Buainain (2010) states that compensation strategies enable the students to make up for missing knowledge in the process of comprehending or producing the target language. Meanwhile, there were 13 students or about $86.67 \%$ used cognitive strategy as their speaking strategy to improve their speaking ability. They mostly used watch films or TV programs in English because it can entertain them, it does not make boring, it makes enjoyment and fun so they are interested in learning English, especially in learning speaking. As what Oxford (1990, p. 43) says that cognitive learning strategy is essential in learning a language. Therefore, it can be assured that the result of the students' speaking 
ability will raise due to the application of the cognitive strategy.

\section{CONCLUSION}

Based on the research findings, it was found that there are SOME strategies used by Indonesian EFL tertiary students when they speak English and improve their speaking ability, namely cognitive, metacognitive and compensation strategy. In the type of speaking strategy that mostly used by the student in terms of speaking English is compensation strategy, while cognitive strategy is indicated as the mostly speaking strategies used by the Indonesian EFL tertiary students in improving their speaking ability.

Considering to the research conducted, there are some recommendations that can be proposed to the teachers and students. It is recommended for the teacher to find the language learning strategies, especially speaking strategies, of their students and help them balance the strategies used by the students based on the students' needs and preferences. The teacher should adapt the teaching strategies with the students learning strategies to enhance students' achievement in learning speaking. For the students itself, they should know what strategies that appropriate and can help them in learning speaking English. The students should be able to choose strategies they need in learning and analyze which strategies which give better effect on their own learning.

\section{REFERENCES}

Al-Buainain, Haifa. (2010). Language learning strategies employed by English majors at Qatar university: Question and queries. Asiatic: IIUM Journal of English Language and Literature, Volume 4, Number 2, December 2010, p. 92-120. Retrieved from http://www.myjurnal.my/publ ic/article-view.php?id=14934 on December 29th, 2015

Argawati, Ningtyas Orilina. (2014). Improving students' speaking skill using group discussion; Experimental study on the first grade students of senior high school. ELTIN Journal, 2(II), p. 74-81. 
Edge, Julian. (1993). Essentials of English language teaching. New York: Longman

Griffiths, Carol. (2008). Lessons from good language learners. Cambridge: Cambridge University Press.

Kustati, Martini. (2003). Students speaking-related language learning strategies in their speaking ability. Padang: Padang State University.

Larenas, Claudio Diaz. (2011). Exploring knowledge of English speaking strategies in 8th and 12th graders. PROFILE, 13(2), p. 85-97.

Liu Dongyue. (2004). EFL proficiency, gender and language learning strategy use among a group of Chinese technological institute English majors. Retrieved from http://www.ecls.ncl.ac.uk/pub lish/Volume

1/Dongyue/Dongyue.htm.pdf on December 29th, 2015.

López, M. M. (2011). Speaking strategies used by BA ELT students in public universities in Mexico. MEXTESOL Journal, 35(1), 1-22.

Malihah, Noor. (2010). The effectiveness of speaking instruction through taskbased language teaching. REGISTER, 3(1), p. 85-101.

Mistar, J., Zuhairi, A., \& Umamah, A. (2014). Strategies of learning speaking skill by senior high school EFL learners in Indonesia. Paper presented at the 10th International TESOL Conference, Manila.

Moriam, Q. M. (2005). Speaking strategy use by the EFL students in Japan and Bangladesh. Journal of International Development and Cooperation, 12(1), 4761.

Nakatani, Y. (2006). Developing an oral communication strategy inventory. The Modern Language Journal, 90(2), 151-168.

Nunan, David. (1999). Language teaching methodology: A textbook for teachers. Kuala Lumpur: Pearson Education. 
O' Malley, J. M. \& Chamot, A. U. (1990). Learning strategies in second language acquisition. Cambridge: Cambridge University Press.

Oxford, R. L. (1990). Language learning strategies: What every teacher should know. New York: Newbury House. 
Jurnal Keluarga Sehat Sejahtera Vol. 16 (32) Desember 2018

p-ISSN : 1693 - 1157, e-ISSN : 2527 - 9041 